NBER WORKING PAPER SERIES

MERIT PAY FOR

SCHOOL SUPERINTENDENTS?

Rona 1d G. Ehrenberg

Richard P. Chaykowski

Randy A. Ehrenberg

Working Paper No. 1954

\author{
NATIONAL BUREAU OF ECONOMIC RESEARCH \\ 1050 Massachusetts Avenue \\ Cambridge, MA 02138 \\ June 1986
}

\begin{abstract}
We are grateful to the numerous school superintendents who responded to the survey used in the paper, to the staff of the COrnel1 Institute of Social and Economic Research for acquiring a number of the data tapes that we used, to Eileen Driscoll for facilitating our use of these data, and most especially, to Jeffrey Keefe for his assistance coding and analyzing data during the early stages of the project. A draft of this paper was written while the first author was a Visiting Professor at Tel-Aviv University and he is grateful to that university for its hospitality. The research reported here is part of the NBER's research program in Labor Studies. Any opinions expressed are those of the authors and not those of the National Bureau of Economic Research.
\end{abstract}




\section{Merit Pay for School Superintendents?}

\section{ABSTRACT}

Given the important role that school district administrators play in the educational process, one might expect their "performance" to be of fundamental importance in determining both how much students learn and the cost of public education to taxpayers. Yet, while public debate has considered the issue of merit pay plans for teachers, virtually no attention has been directed to the methods by which school administrators are compensated.

This paper provides evidence on whether school superintendents are explicitly or implicitly rewarded for their "performance" by hlgher compensation and or greater opportunities for mobility. We analyze panel data from over 700 school

- districts in New York State during the 1978-79 to 1982-83 period. Measures of performance are defined and then entered into salary level. salary change, and mobility equations. While evidence is provided that school superintendents are rewarded for "performance", the magnitude of the rewards appear to be quite sma 11 .

Ronald G. Ehrenberg New York State School of Industrial and Labor Relations Cornell University Ithaca, NY 14851-0952
Richard P. Chaykowski Eaculty of Economics and Industrial Relations Queen's University Xingston, Ontario
Randy A. Ehrenberg DeWitt Middle Schoo: Ithaca, NY 14850 


\section{Introduction}

The April 1983 report of the National Commission on Excellence in Education, A Nation at Risk, focused public attention on the need to reform public education. Among its most hotly debated proposals was one to institute merit pay plans for teachers; this in spite of the fact that hlstorically merit pay plans have not met with much success in public education, at least partially because there are characteristics of public education that make their implementation problematic. ${ }^{1}$

Somewhat surprisingly, less attention has been directed to the important role that educational administrators (school principals and superintendents) play in the educational process and their methods of compensation. Given their key roles in a variety of areas, including the recruitment and continual motivation of teachers, the design of curriculum, the setting of educational goals, and their management of school district resources, one might expect administrators" "performance" to be of fundamental importance in determining both how much students learn and the cost of public education to taxpayers. ${ }^{2}$ Yet there has been little public call for formal merit pay plans for school administrators. This is somewhat puzzling because studies of individual (as opposed to group) merit or incentive pay plans in the for-profit sector of the economy find that they tend to be concentrated at upper levels of management, where fundamental policy and managerial decislons are made, rather than covering all employees. ${ }^{3}$ 
In fact, while there is a volumingous literature on the determinants of teachers' salaries, we know little about the forces that influence the compensation of school administrators. 4 In particular, we have little evidence about whether they are explicitly or implicitly rewarded for their "performance" by higher compensation and or greater opportunities for mobility to higher paying positions. 5 Such evidence is clearly important for policy debate; unless there is evidence that school administrators' compensation is at least implicitly tied to their "performance", a case can be made that consideration should be given to bullding incentives for performance explicitly into their compensation arrangements.

To shed evidence on these issues, this paper presents analyses of the compensation and mobllity of school superintendents in New York State during the 1978-79 to 1982-83 period. $^{6}$ Our analyses are based on a unique longitudinal data base we have assembled that include the salary and name of the school superintendent in each school district in the state cover 700) each year during the five-year perlod. Coupled with data from a variety of other sources, these data enable us to estimate the extent to which, across districts at a polnt in time, a superintendent's salary is related to characteristics of the school district (e.g., community wealth and adult educational attalnment), characteristics of the superintendent (e.g., educational attainment and experlence), and measures of the superintendent's "performance". Similarly, they enable us to 
estimate the extent to which superintendents' salary changes and probabilities of mobility, are related to "performance".

Of course, a crucial element in our study is the definition of "performance". While school districts and their school board members are idiosyncratic and, as we demonstrate below, evaluate superintendents' performance in a wide variety of ways, our methodology is to focus on a few well-defined outcomes. Specifically, we assume that school districts value high educational performance and low school tax rates, each relative to the comparable outcome in "similar" school districts in the state. 7 Specifically, we define performance by contrasting actual student test scores and the tax rate for each district in a year to predicted values obtained from regression equations in which each outcome is specified to be a function of characteristics of the district (e.g., income level, wealth, adult education levels, racial $\mathrm{mix}$ ). Such a methodology proved useful in a previous study conducted by one of us that dealt with the compensation of city-managers, police chiefs and fire chiefs. 8

We begin in the next section by presenting background data on the salaries and mobility of school superintendents in New York State, along with estimates of cross-section superintendent salary equations that exclude performance measures. Based upon a survey we conducted of all school superintendents in New York State, section III discusses the crlteria superintendents believe are used in their evaluations and, with these results in mind, 
discusses the performance measures actually used in this study. Section IV then presents our estimates of the effects of performance in one year on the next year's salary level for superintendents who remain in the same district, as well as our estimates of the effects of performance and changes in performance on the salary changes of superintendents who remain in the same district or move to another school district in the state. The next section presents estimates of the relationship between the mobility of school superintendents and their performance. Finally, Section VI presents some brief concluding remarks.

II. Salaries and Mobility of School Superintendents in New York State, 1978-79, to 1982-83: Some Freliminary Anaiyses

Descriptive statistics are presented in Table 1 on school superintendents" salaries in New York State during the five academic year period that our data cover. There are over 700 public school districts in New York State and excluded from the data each year are New York City, districts in which the position is vacant, and districts that falled to report salary information. The mean salary of superintendents in the sample rose from slightly under $\$ 35,000$ in $1978-79$ to over $\$ 44,000$ in 1982-83. Each year the variation in salaries across districts was large: for example in 1982-83 superintendents in the state earned betweer. $\$ 20.000$ and $\$ 71.000$, with the standard deviation in salaries equalling almost $\$ 10.000$. Much of this variation is clearly due to the wide varlation of school district sizes in the 
sample, however, as we demonstrate below, other factors are also important.

Background data on the mobility of school superintendents in the state is found in Table 2. From our data, we can track if a superintendent remained in the same school district for two consecutive years, moved from one district to another school district in the state during the period, or moved from one school district in the state to "out of sample" status. In the latter case, the superintendent may have retired or died, may have moved to another superintendency outside of New York State, may have moved to a different educational position (nonsuperintendent) in another district in the state, or may have switched to a noneducational position. Alternatively, his school district may simply have falled to report data in the second year.

The data in Table 2 suggest that the annual turnover rates - of school superintendents are low, as each year between 81 and 88 percent of the superintendents continued in their current job. Only 4 to 6 percent of the superintendents moved to another district in the state, while 8 to 13 percent of the superintendents dropped out of the sample each year. In Section $V$ we attempt to explain, using multinomlal logit analyses, the determinants of which of these three "states" a superintendent is in each year. Since our data do not permit us to distinguish among the variety of reasons that an Individual winds up in the "out of sample" state, not surprisingly our ability to "explain" why individuals wind up in it is limited. 9 
Ignoring "performance" for a moment, what are the forces one might expect to influence a superintendent's salary? On the one hand, one might expect that the characteristics of the school distrlct should matter as larger districts (where a superintendent's job is more difficult), wealthier districts (who can afford to pay more), districts that contain a high proportion of highly educated adults (who are likely to have a strong

- "taste" for education), and districts whose students have special educational needs (such as those with a large proportion of minority students), are all likely to pay higher salaries in an effort to attract and retain high quality superintendents. On the other hand, characteristics of the superintendent should also matter, as more experienced and more highly educated superintendents are likely to be able to command higher salaries.

Table 3 reports our attempts to see if these forces do matter. Estimates of annual cross-section salary equations of the form

$$
\text { (1) } \log \left(w_{i}\right)=a_{0}+a_{1} x_{i}+a_{2} s_{i}+\varepsilon_{i} \text {, }
$$

where $W$ is the annual salary of the superintendent, $X$ is a vector of school district characteristics, $s$ is a vector of characteristlcs of the superintendent, and $\varepsilon$ is a random error term, are reported there.

As noted in the table, the school district data used in the analyses come from a variety of federal and state sources. The characteristlcs of the superintendents come from two volumes of Whe's who in Educational Administration, the directory of members 
of the American Association of School Administrators, and the responses to a survey of all school superintendents employed in New York State in 1984-85, that was conducted by the authors in late May to early July of 1985. Because less than half of the superintendents in the sample belonged to the professional association and the response rate of incumbents in 1984-85 to the survey (and a follow-up for nonrespondent) was about 70 percent, there was a substantial number of observations with missing data on some, or all, of the superintendents' characteristics. We also could not obtain school district characteristics data for some of the districts. As a result, we excluded observations from the sample if elther the school district's characteristics or the superintendent's degree information was missing. 10 As Table 3 indicates, this reduces our sample sizes to between 550 and 600 observations each year.

As expected, the characteristics of school districts prove to be important determinants of superintendents' salaries. Ceterls paribus, in each year larger districts sas measured by the logarithm of total enrollment $\left.\left(x_{1}\right)\right)$, wealthier districts (as measured by the logarlthms of property values per enrolled student $\left.\left(x_{2}\right)\right)$, per capita personal income in the county $\left(x_{3}\right)$, or census year (1979) median famlly income in the school district $\left(x_{4}\right)$, and districts that place a high value on education (as measured by the percentage of the distrlct's adult population with greater than a college degree $\left(X_{6}\right)$ ) all are associated with hlgher superintendents' salaries. 
In contrast. only two of the superintendents' characteristics. years of tenure in the current district $\left(S_{4}\right)$ and years since receiving a bachelor's degree $\left(S_{5}\right)$-- the latter a rough proxy for age -- prove to be statigtically significant. Moreover, quantitatively the effects of these variables are very small, with the rate of return per year of tenure being roughly 0.6 percent and that per year of age being roughly 0.2 percent. Somewhat surprisingly, neither the possession of a doctorate degree $\left(S_{1}\right)$ or a certificate of advanced study in adninistration $\left(S_{2}\right)$-- the latter an intermediate degree between a masters and a doctorate -- nor the total number of years of previous experience as a superintendent in other school districts, systematically are associated with salary. 11

of course, it is well-known, and the results of our survey confirm, that the typical mobility pattern of a superintendent (at least during the early stages of his careefs) is from smaller to larger and or from poorer to wealthier districts. If this is the case, these personal characteristics variables may affect salary indirectly via influencing the characteristics of the school district in which the superintendent is located, rather than directly influencing his salary level, given his district's characteristics.

To test this hypothesis, the logarithm of property value per enrolled student and the logarithm of total enrollment in the superintendent's district were each regressed on the personal characteristics of the superintendent sexcluding years of tenure 
in the current district). The results are reported for each year in Table 4. Having a doctorate degree, having more prior experience as a superintendent in other districts, and being older, all are associated with employment in larger school districts, while having a doctorate degree also is associated with being employed in wealthler districts.

These latter findings have important implications for the analyses that follow of the relationship between compensation and performance. For even if within a given school district one was to $f$ ind no relationship between a superintendent's compensation and his performance, superintendents might st 111 be rewarded for performance by increased opportunities for mobility to better paying positions.

II . Evaluating the "Performance" of School Superintendents We measure the performance of a school superintendent in thls paper by his success in keeping school tax rates low and educational test scores high in his district, both relative to these outcomes in "comparable" districts in the state. It is natural to ask how these measures correspond to the criteria that superintendents believe school boards actually use? To answer this question, the survey of school superintendents that we conducted asked the respondents to list the criterla they believed their school boards used in thelr evaluation. 12 In cases where a formal evaluation instrument exlsted, the superintendent was asked to attach it to hls response. ${ }^{13}$ 
Approximately 80 percent of the respondents to our survey 397 of 496) included a list of criteria in their response and about 25 percent of these ( 86 ) attached formal evaluation instruments.

A preliminary scanning of the responses suggested that the criteria mentioned could be classified into twelve broad categories and a count was made of the number of times each category was mentioned. These responses are tabulated in Table 5; since most superintendents mentioned more than one category, the total count across categories far exceeds the number of respondents.

Most striking, and somewhat depressing (at least to us!), the most commonly mentioned criteria were community/public relations and school board relations. Fiscal management (the category that would include keeping tax rates low) came in fourth on the list and was mentioned by about two-thirds of the respondents. Academic performance and achievement, (the category in which keeping test scores hlgh would fall) was eighth on the list and was mentioned by less than one-third of the respondents. What are the implicatlons of these findings for the use of the objective performance measures that we propose? On the one hand, it is hard to envision objective measures that are readily avallable for the other ten criteria; measures of fiscal management and academic performance and achievement may be the best one can do. On the other hand, it ls clear that the specific measures we use are measured with considerable error; if these errors are random the coefflclents of our performance 
variables will be biased towards zero in the compensation and mobility equations. Furthermore, given that more than twice as many respondents mentioned $f$ iscal management as did academic performance, one might expect that, on average, the former will prove to be more important than the latter in explaining compensation and mobility.

To give the reader a feel for how the performance measures were actually constructed, Table 6 presents estimates of tax rate and educational outcome equations for 1979-80 sseparate equations were estimated for each year and the results are very similar across years). The tax rate variable is the logarithm of the full-value property tax rate in the school district. The educational outcome variables are the logarithms of the percentage of the district's students who fall below the state reference point on a standardized sixth grade mathematics examination and the average percentage who fel't below the state reference point on standardized third and sixth grade reading and mathematics examinations. 14 Students who fall below the state reference point are deemed to require remedial services and state ald is increased to help fund these services. Since these outcome scores measure the proportion who "fail" these tests, we are focusing on the bottom tail of the academic achievement distribution. 15

For each of these three outcomes $(0)$, equations were estimated of the form

$$
\text { (2) } \log 0_{j}=b_{0 j}+b_{1 j} z+u_{j} \quad J=1,2,3
$$


where $Z$ is a vector of school district characteristics expected to intiuence these outcomes and $U$ is a random error term. In fact, the variables in $Z$ are assumed to be ldentical to those that enter the superintendent salary equation $(x)$, save that a $(1,0)$ "city school district" dummy varlable replaces the continuous size of district variable. In the large city school districts in New York State the property tax rate is set by an elected school board (subject to constitutional limitations), while in the smaller school districts the tax rate is set each year by a voter referendum. One might conjecture, ceteris paribus, that in the latter situation direct voter control will lead to lower tax rates.

In the main. the estimates in Table 6 conform to our expectations and provide reasonable explanations of the tax rates and test scores. For example, with respect to tax rates, wealthier $\left(x_{2}\right)$ districts have lower tax rates. presumably because lower rates are required to raise any glven level of revenue, richer in terms of current income $\left(x_{4}\right)$ districts have higher tax rates, districts with higher proportions of nonwhites $\left(x_{5}\right)$. and thus special needs, have higher tax rates, and districts with higher proportions of adults with more than a college education $\left(x_{5}\right)$, and presumably greater taste for ecucation, have higher tax rates.

Similarly, with respect to test scores, wealthier districts, districts with higher current income and districts with highly educated adults. ceteris paribus, all have lower failure rates on 
the tests, whlle districts with a higher proportion of nonwhites have higher fallure rates. Fallure rates, but not tax rates, also appear to be higher in the "city" school districts. It is worth noting that the equation used to predict the average test fallure rate "fits" much better than the equation used to predict the sixth grade math test failure rate. While it would be preferable to use the former in our analysis, as noted above (footnote 14) only the latter can be used in analyses that exploit the longitudinal nature of the data.

Given these estimated coefficients (corresponding to $\hat{b}_{0}$ j and $\hat{b}_{1 j}$ in (2)), one can obtain estimated values of the logarithm of each outcome for each school district (i) from

$$
\text { (3) } \log 0_{j i}=\hat{b}_{0 j}+\hat{b}_{1 j} z_{i} \quad J=1,2, \ldots .3 \text {. }
$$

The school district (='s superintendent's) performance is then defined as the difference between the predicted and actual values of the log of each outcome.

$$
\text { (4) } P_{j i}=\log 0_{j i}-\log 0_{j i} \quad j=1,2, \ldots 3 \text {. }
$$

Positive values of $P_{j l}$ indicate positive performance for the superintendent, as positive values would occur only when predicted tax rates (or fallure rates on tests) would exceed actual tax rates (or failure rates on tests) in the school district. 
It is worth reemphasizing that (2) (3) and (4) are estimated separately each year. Thus, the structural equations that generate the performance measures are allowed to vary across years, as are the estimates of tax and test score performance in the district. This allows us to focus on the effects of changes in performance on changes in salaries and mobllity in places be low.

IV. Salary Levels, Salary Changes, and Performance

We begin our analyses of the relationship between superintendents' performance and salaries by focusing on Individuals who remained in the same position for two consecutive years, asking if estimates of their performance in the first year influenced their salary levels in the second year. 16 Specifically, we estimate equations of the form

$$
\text { (5) } \begin{aligned}
\log w_{i t} & =a_{0 t}+a_{1 t} x_{i t}+a_{2 t} s_{1 t}+a_{3 t} T_{1 t-1} \\
& +a_{4} E_{i t-1}+\varepsilon_{1 t} .
\end{aligned}
$$

where $T_{1 t-1}$ is our neasure of the "tax performance" of the superintendent in period $t-1, E_{1 t-1}$ is our measure of the "educational test score performance" (either the sixth grade math test or the average of all the tests) of the superintendent in perlod $t-1$, and all other variables are defined as before (see Table 3). Equation (5) ls estimated separately for each of the last four academic years in our sample $c t=1979-80,1980-81$. 
1981-82, and 1982-83) and for the four years data pooled together; in the latter case, separate intercept terms for each year are included in the model. 17 Given our definitions of performance, the coefficients $a_{3}$ and $a_{4}$ are expected to be positive.

Table 7 presents the estimated coefficients of the performance variables from these models; the coefficients of the other explanatory variables are virtually identical to the coefflcients that appear in Table 3. Taken together, especially when one focuses on the pooled results, these coefficients suggest that while higher educational performance is associated with higher superintendents' salaries as expected, higher tax performance is associated with lower superintendents' salaries for this sample of stayers. How can one reconcile these apparently contradictory findings?

On the one hand, one might argue that the labor market for superintendents is not operating totally in the manner that we expected. On the other hand, and we prefer this explanation, one might argue that our model may be imperfectly speclfied and that some important explanatory variable that belongs in the vector $x$ has been omitted from the model. That 19, our estimates are subject to omitted variable bias.

To see this, suppose there is some unobserved variable, whlch we denote by $v_{1 t}$, that measures the intensity of a community's feelings about the importance of education and the willingness of the community to pay a high salary to attract a 
first-rate superintendent, and that this variable is rot fully controlled for by the $x^{\prime} s$ in our model. Hence, the "correct" model should be

$$
\text { (6) } \begin{aligned}
\log w_{1 t} & =\alpha_{0 t}+\alpha_{1 t} x_{1 t}+\alpha_{2 t} S_{1 t}+\alpha_{3 t} T_{i t-1} \\
& +\alpha_{4 t} E_{i t-1}+v_{1 t}+\varepsilon_{1 t}
\end{aligned}
$$

Districts with high values of $V$ are also likely to tax themselves at higher rates to support education than other districts, ceteris paribus. As a result, our estimated tax performance measure will be low in these districts and the partial correlation between $T$ and $V$ will be negative. Similarly, districts with high values of $V$, where more resources than predicted are devoted to education, are also likely, ceteris paribus, to be districts in which student test scores are high and fewer students fall below the state norm on the standardized tests. As a result, our estimated test score performance measures will be high in these districts and the partial correlations between $E$ and $V$ wlll be positive. It is stralghtforward to show that if one estimates (5) rather than (6), omitting $v_{i t}$, the tax performance coefficient will be blased in a negative direction and the educational performance coefficients biased in a positive direction. 18 One can thus not be sure how to interpret the coefflcients in Table 7.19

Of course, if one ls willing to assume that the $V_{j t}$ do not vary over time in a given district $\left(V_{1 t}=V_{j}\right)$, an innocuous assumption given the short time span of our data, equation ( 6 ) 
becomes a fixed-effects type of model. 20 At first glance, an apparent solution to the omltted variable bias that may be present, is to treat all parameters ssave for the intercept terms) as constant and first-difference to obtain.

$$
\text { (7) } \begin{aligned}
\log \left(w_{i t} / w_{i t-1}\right) & =\alpha_{0 t}+\alpha_{1}\left(X_{i t}-X_{1 t-1}\right)+\alpha_{2}\left(S_{i t}-S_{i t-1}\right) \\
& +\alpha_{3}\left(T_{i t-1}-T_{i t-2}\right)+\alpha_{4}\left(E_{i t-1}-E_{i t-2}\right) \\
& +\left(\varepsilon_{i t}-\varepsilon_{i t-1}\right) .
\end{aligned}
$$

Equation ( 7 ) can be estimated directly and, since $v_{1}$ does not appear in it, unblased estimates of $\alpha_{3}$ and $\alpha_{4}$ obtained. That is, one can estimate the extent to which changes in performance are associated with changes in salary.

Unfortunately, matters are not always as simple as might appear at flrst glance; equation ( 7 ) must be modifled for two reasons. First, as noted in Table 2, each year some superintendents move to new jobs within New York State and others drop out of the sample. Since we have subsequent earnings data for the former, we can include them in the analyses and allow the effects of all of the right-hand side variables in the model to differ for movers and stayers; this will enable us to estimate the effect of mobility within the sample per se on earnings growth. 21 . However, we must stress that selectivity problems abound here, whether a superintendent moves to another district in the state or drops out of our sample presumably are not random events. To econometrically model this joint wage-change-job- 
change-leave-the-sample process would be extraordinarily complex, especially so since both school boards and superintendents are involved in the decision process. In the remainder of this section, for empirical tractability we ignore sample drop-outs and treat within-sample mobllity as exogenous, whlle in the next section we analyze mobility directly.

Second, if equation ( 6 ) is indeed the true model, then changes in salary should be related to changes in performance, as in (7). However, it is not obvious that the specification in (6) is correct, for it is conceivable that school districts may want to reward superintendents for keeping performance high, even if it is not improving. So, for example, as long as educational test scores in a district are 10 percent above their predicted value, the superintendent might recelve an above average salary Increase, even if he simply is maintaining the existing differential. Because of this, in what follows we also estimate models that include performance levels as explanatory variables, as well as those that include performance changes.

Table 8 presents estimates of several salary change equations for superintendents who remained in the sample over two consecutive years. Column (1) presents the simplest model; salary change is postulated there to be a function only of year dummy varlables and a dichotomous variable for whether the superintendent changed jobs ( $1=$ yes, $0=$ no) during the period. 22 The results in this column suggest that mobility mattered; on average superintendents who changed jobs received salary 
increases tnat were $b$ percent higher than those who remained in the same position. To say that on average "movers" galn is not to say, however, that mobility always pays. In fact approximately one-fifth of the movers each year failed to increase their salarles; some of these suffered salary losses as large as 30 percent.

Columns $(2)-(4)$ present the results of estimating variants of equation ( 7 ). Each specification includes the changes in the logarithms of income, enrollment. and full value of property per student in the district, as well as the tax and educational pertormance measures. 23 The coefficient of each of these variables is allowed to differ between movers and stayers. As discussed in Section III. since we are now exploiting the longitudinal nature of the data, the only educational performance measure that can be used is that based on the sixth grade math test: this was the only test that did not change during tine fiveyear period.

Three different forms of the performance measures are used. In the specification in column (2) we use the change in performance measures. So, for example, if we are looking at the salary change from 1979-80 to 1980-81, the relevant performance change measures would be those from 1978-79 to 1979-80. Columns (3) and (4) use level of performance measures. The former uses the base year performance measures: in our example, 1979-80. The latter uses a iagged year performance measure; in our example, $1978-79$. 
Turning to the results, in these specifications, ceteris paribus. movers suffer salary losses in the range of 5 to 6 Dercent relative to superintendents who don't change jobs. This occurs because among the other things held constant here are school district income, enrollment, and wealth per student. In fact. the changes in each of these variables is positively assoclated with salary changes for movers (but not for stayers). Hence, in order for superintendents to gain from mobility, they must move to either higher income, larger, or wealthier school districts. 24

At irst glance, column (2) suggests that the change in math performance is perversely negatively associated with the superintendent's salary change for stayers. However, when the base year and lagged year math performance index are included as separate variables (not reported here) both prove to be statistically insignificant. Moreover, columns ( 3 ) and (4) suggest that the negative association between salary change and math test periormance change occurs primarily because the lagged level of math performance is positively associated with the salary change. To show that the lagged level is indeed the relevant variable that should enter into the salary change equation, a discussion of the timing of these variables is in order.

Returning to our example, suppose again that we are trying to explain the determinants of the 1979-80 to $1980-81$ salary change for a superintendent. The base year math test (for 1979- 
80) was given in the spring of 1980 and the district mignt have recelved its own test results back shortly thereafter. There is

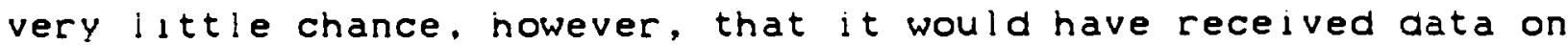
the test scores in other districts in the state prior to the next academic year (the fall of 1980). Such information would have come too late to be used in the process of deciding the superintendent's salary for 1980-81; presumably such a decision would have to have been made prior to the fall of 1980 . So, in fact, neither the base year level of the math performance measure, nor the change in the performance measure (as we have defined it) could logically have been used in making the salary change decision. The lagged math performance measure is, in a temporai sense, a logically correct variable to use and it is positively associated with salary changes for superintendents who do not change joDs.

What about the effects of performance on the salary changes of superintendents who change jobs? Here the evidence is a bit more mixed. The derived estimates ffrom the stayer and interaction coefficlents) of the effects of performance on movers salary changes are found in the notes to Table 8 . Following the same reasoning as above, it is the lagged performance level variables that logically might effect salary changes. However, while lagged tax performance is positively associated with earnings gains for superintendents who change Jobs, lagged matin test periormance is negatively associated. 


\section{Pertormance and Mobility}

As Table 2 indicates, each year roughly 5 percent of the superintendents in our sample moved to another school district in New York State, while roughly 10 percent dropped out of the sample. Among the former group, approximately 80 percent recelved salary increases, while 20 percent recelved the same salary after moving or suffered wage cuts. Finally, approximately 85 percent of the sample continued in their same positions. What determines in which of the four states (move to another district with $\dot{S}>0$, move to another district with $\dot{s} \leq 0$, leave the sample, or stay in the same position) each observation is located?

To answer this question, we estimated models of the form

$$
\begin{gathered}
\text { (8) } \log \left(\frac{p(\text { state }=j)}{P(\text { state }=4)}\right)=d_{0 j}+d_{1 j} Y+d_{2 j} s+d_{3 j} T+d_{4 j} E+\varepsilon_{j} \\
j=1,2,3
\end{gathered}
$$

where $Y$ is a vector of characteristics of the school district (a subset of the $x$ ), S is the vector of superintendent characteristics, and $T$ and $E$ are the relevant tax rate and educational test score performance measures. The notation $P(s t a t e=j)$ denotes the probability that an individual is in state $j$, with the four states being change districts with a salary increase, change districts with no salary increase or a salary decrease, leave the sample, and continue on in the same district. respectively. Under suitable assumptions about the distribution of the error terms (lognormal) the system in ( 8 ) 
represents a multinomial logit model and can be estimated by standard maximum 1 ikel ihood methods. 25

Table 9 presents the estimates of one specification of equation ( 8 ) (that uses the lagged level performance measures), both for the 4-way dichotomy that includes people who left the sample and the 3-way dichotomy that excludes this group. The table indicates that the vectors of parameters that determine the logarithm of the ratios of the odds of being in the other three groups is virtually identical for the two models; this is to be expected given the "irrelevance of alternative option" property of the multinomial logit model.

Quite striking, the lagged tax level performance measure is positively associated with the odds of moving to a higher paying job (relative to staying) and negatively associated with the odds of moving to a lower paying job relative to staying. Put another - way, among movers the better lagged tax level performance is, the more likely the individual will move to a better job. On-the-job financial performance does affect school superintendents' futures. The math performance variable, however, is always insignificant, perhaps because of the reasons discussed in Section III.

As suggested from the cross-section results found in Table 4, having a doctorate degree increases a superintendent's chances of moving to a better paying job relative to his chances of not moving. Older superintendents are less likely to move to another job, and more likely to leave the sample, both relative to 
staylng in the same district. The former clearly reflects voluntary mobility declining with age and the latter reflects retirement rates increasing with age. Superintendents with more previous experience as a superintendent in other districts are more likely to move to both higher or lower paying jobs relative to staying in the same district: this may well reflect heterogeneity of turnover probabilities. 27 Finally, being employed in a school district with high median family income reduces the probability of moving to a higher paying job relative to the prodability of staying. As indicated in Tabie 3 , higher income school districts pay more, thereby reducing the likely gain to mooility.

In fact, this latter result suggests that some measure of the superintendent's potential gain from mobility should be directly included in these equations. We experimented with four such measures: the logarithm of his base year salary, his residual from a base year log salary equation that included only superintendents characteristics, his residual from a base year log salary equation that included both superintendents' and school district characteristics, and his residual from a comprenensive Dase year log salary equation that also included pertormance measures. However, none of these measures proved to be statistically significant (when they were included one at a times. nor did their inclusion affect the pattern of signs and significance of the coefficients in Table 9 . 
Finally, Table 10 indicates the sensitivity of our mobility results to the specification of the performance variables. As in the salary change equations, four specifications were tested: base year level, lagged year level, both base and lagged year levels, and change in performance. The coefficlents in this table indicate quite clearly that only the lagged level of tax performance matters, with better performance leading to an increased (decreased) probabllity of mobility to a better paylng (not better paying) position relative to the probability of remaining on the same job. 28

\section{Concluding Remarks}

Are school superintendents rewarded for "good performance" by larger salary increases and/or greater opportunities for mobility to higher paying positions?. Although the evidence we have presented is not totally unambiguous, our..tentative answer 1s yes. Higher scores on the tax rate performance index in the prior year are associated with greater (smaller) probabilities that a superintendent will move to a better (poorer) paying job relative to the probability of staying in the same district and, for "movers". larger salary increases. Higher scores on the third grade mathematics test index in the prior year are associated with larger salary increases for stayers. However, contrary to our expectations, this index is also negatively associated with salary increases for movers. It is this latter finding that gives us some pause as we draw conclusions. 29 
Of course, as noted above, there. are many problems with our educational performance index. It is based on a single subject and grade level test and focuses on the lower tail of the academic achievement distribution. This causes us to put more weight on the tax rate findings, but also suggests that future researchers might profitably examine a wider range of educational outcome measures than we have.

Moreover, to say that the market for school superintendents is implicitly behaving "as if" there were merit pay for school superintendents is not to say that the implicit incentives to perform that superintendents face is sufficiently strong. Given the responses to our survey's question on the criterla school boards use in their evaluation of superintendents (Table 3), our priors would lead us to be surprised if they were. Indeed, our own estimates do suggest that these incentives are quite modest.

For example. the estimated coefficients in Table 8 suggest that a superintendent who remained in the same district and kept his district's math test performance index one standard deviation above the mean performance index (which is zero), would receive an annual salary increase that was only 0.3 percentage points higher, ceteris paribus, than a "mean performer". 30 If the superintendent maintained this level of performance over a tenyear period he would find his salary level at the end of the period only slightly more than 3 percentage points higher. ceteris paribus. than that of the mean performer. Similarly. they suggest that. among superintendents who moved to another 
position. Those whose alstrict's tax rate performance index was one standara deviation above the mean tax rate performance (which again is zero', would recelve a salary increase upon moving that was only 1.7 percentage points higher, ceter is paribus, than the salary increase that a "mean performing mover" would recelve. 31 Nelther of these magnitudes would appear to provide a strong incentive for superintendents to perform well.

On the other hand, the coefficients in Table 9 do suggest that tax rate performance does substantially influence mobility prospects. Ceteris paribus, a superintendent whose district's tax rate performance was one standard deviation above the mean would increase the ratio of his probability of moving to a better paying job relative to his probability of staying in the same district by 40 percent and decrease the ratio of the probability of his moving to a poorer paying job relative to the probabllity of staying dy 37 percent. 32 These ratios, however, on average are very small-- .038 $(46 / 1207)$ and $.016(19 / 1207)--$ so one may question whether even these mobility effects are of sufficient magnitude to provide the approprlate incentives for periormance. As such, some education of school board mempers on the potential gains from using formal merit pay plans that focus on desired educational and financial outcomes, rather than on public relations type measures, may well be in order. 


\section{Beferences}

American Association of School Administrators, Compensating the Superintendent (Arlington, VA, 1979).

American Association of School Administrators, Who's Whe in Educational Administration (Arlington, VA, various years).

Samuel Bacharach, David Lipsky and Joseph Shedd, Paying for Better Teaching: Merit Pay and Its Alternatives (Ithaca, NY, Organizational Analysis and Practice, Inc., 1984). Michael Berger, "Predicting Succession Under Conditions of Enrollment Decline" (Presented at the Annual Meeting of the American Educational Research Association, Montreal, Canada, April 1983).

S. Bossert, D. Dwyer, B. Rowan and G. Lee, "The Instructional Management Role of the Principal," Educational Administration Quarterly 18, 1982,34-64.

G. Chamberlain, "On the Use of Panell Data" in J. Heckman and B. Singer, eds., The Analysis of Lonaitudinal Labor Market Data (Academic Press, 1981).

Ronald G. Ehrenberg and Joshua L. Schwarz, "Public Sector Labor Markets" in Orley Ashenfelter and Rịchard Layard, eds.. Handbook of Labor Economics (North Holland, 1986).

Gerald Goldstein and Ronald Ehrenberg. "Executive Compensation in Municipallties," Southern Economic Journal 43, July 1976. 937-947.

2v1 Griliches, "Estimating the Returns to Schooling: Some Econometric Problems," Econometrica 45, January 1977, 1-22. 
Phillip Hallinger and Joseph Murphy. "The Superintendents Role in Promoting Educational Leadership," Administrator's Notebook, $x \times x(1982)$, No. 6 .

Jerry Hausman, "Specification Tests in Econometrics,"

Econometrica 46, November 1978, 125-171.

James Heckman, "Sample Bias as a Specification Error,"

Econometrica 47 , January $1979,153-162$.

James Heckman, "Heterogeneity and State Dependence" in S. Rosen, ed., Studies in Labor Markets (University of Chicago Press, 1981).

Mlchael Jensen and Jerold Zimmerman, "Management Compensation and the Managerial Labor Market," Journal of Accounting and Economics 7, April 1. 1985, 3-9.

Steven Knezevich, The American School Superintendent CWashington, DC, American Association of School Superintendents, 1971). David J. Kroeze, "Effective Principals as Instructional Leaders: New Directions for Research," Administrator's Notebook, XXX (1982), No. 9 .

David Lipsky, "The Effect of Collective Bargaining on Teacher

Pay: A Review of the Evidence," Education Administration Quarterly 18, Winter $1982,14-42$.

G. S. Maddala. Econometries (New York, NY: McGraw-Hill, 1977).

G. S. Maddala, Limited-Dependent and Qualltatlve Varlables in

Econometrics (Cambridge, England: Cambridge University Press, 1983). 
James C. March and James G. March, "Almost Random Careers: The Wisconsin School Superintendency: 1940-72," Bdministrative Science Quarterly 22, September 1977, 377-409.

James C. March and James G. March, "Performance Sampling in

Social Matches," Administrative Scjence Quarterly 23, December $1978,434-453$.

Robert Masson, "Executive Motivations, Earnings and Consequent Equity Performance," Journal of Political Economy 79, December $1971,1278-1293$.

George Milkovich and Jerry Newman, Compensation (Plano, TX:

Business Publications, 19842.

Yair Mundlak, "On the Pooling of Time-Series and Cross-Section Data," Econometrica 46, January 1978, 69-85.

Richard J. Murnane, "The Rhetoric and Reality of Merit Pay: Why Are They Different?" Project Report No. 84-A20 (Institute - for Research on Educational Finance and Governance, Stanford Unlversity, July 1984).

Kevin J. Murphy, "Incentives, Learning, and Compensation," Journal of Labor Eronomics (forthcoming).

Natlonal Commission on Excellence in Education, A Nation at Risk: The Imperative for Educational Reform (Washington, DC, April 1983).

David Schmittlein and Donald Morrison, "On Individual Level

Inference in Job Duration Research: A Reexamination of the Wisconsin School Superintendents Study," Administrative Science Quarterly 26, March 1981, 84-89. 


\section{Eootnotes.}

1. See, for example, Samuel Bacharach, David Lipsky, and Joseph Shedd (1984) and Richard Murnane (1984) for discussions of the difflculties Involved with merit pay plans for teachers. Among the problems they highllght are the often zero-sum nature of such plans (a fixed sum to divide among teachers), the difflculties of measuring individual teacher performance, and the hlstoric opposition of teachers' unions to merit pay.

2. Studies of "effective schools" (where students "performance" exceed one's expectations, given the characteristles of the students, their environment, and the resources devoted to their education) point to the important Instructional leadership role of the principal. For discussions of the effective school literature, see $S$. Bossert, et al. (1982), David Kroeze (1982), and Phlllip Hallinger and Joseph Murphy (1982).

3. See George MIIkovlch and Jerry Newman (1984). Indlvidual incentive plans should be distinguished from group Incentive plans, such as profit-sharing plans, that tend to cover a wider range of employees. The latter have become more prevalent in recent years as a substitute for wage increases in Industrles facing serious economic problems.

There 19, of course, a large theoretical literature on the Importance of structuring private sector corporate executives compensation so that they have incentives to perform in the best interest of shareholders (i.e.. to solve the principal-agent 
problem). A substantial empirical literature, see for example Michael Jensen and Jerold Zimmerman (1985), who summarize a symposium in the May 1985 issue of the Journal of Accounting and Economics, addresses whether such a nexus appears to exist in the private sector: Our work is in the spirit of these latter studies. Somewhat surprisingly, however, there is only a very limited empirical literature on whether private sector corporations that tie executive compensation to "performance" actually "outperform" other firms. Robert Masson (1971) is an example of this literature.

4. For surveys of the teachers salary literature, see Ronald Ehrenberg and Joshua Schwarz (1986) and David Lipsky (1982).

5. Some case studies and statistical analyses of superintendents' turnover and mobility have been conducted; see, for example. Michael Berger (1983), Steven Knerevich (1971), and James C. March and James G. March (1977, 1978). Some comparative data on superintendents' salaries has also been published; see, for example. American Association of School Administrators (1979) and Knezevich. None of these, however, attempted to measure "performance" and to see if it matters; indeed, March and March (1977) argued that the mobility of superintendents is almost a random process. Their approach, however, was criticized by David Schmittlein and Donald Morrison (1981).

6. Our focus is on school superintendents because they are the chief operating officers of school districts and their 
salarles are determined through individual "negotıations" with school boards. In contrast, especially in larger districts, school principals tend to be members of a union and their salary increases negotiated collectively: this limits the likel ihood of observing Individual principals' salaries being related to their performance.

7. A district can simultaneously have high test scores and low tax rates, relative to "comparable" districts in the state, if the districtis administrators efficiently manage both financlal and educational (1.e., staff) resources and effectively motivate school district personnel.

8. Gerald Goldstein and Ronald Ehrenberg (1975).

9. Previous studies suggest that the vast majority of superintendents, possibly as high as 90 percent, serve in only one state during their lifetime (Knezevich (1971)). Thus, it may be reasonable to assume that the number in this last category who move out of state in our sample is sma!l.

10. As noted in the table, between 20 to 65 percent of the observations were missing at least one of the other superintendents' characteristic variables. To omit these observations would have decimated our sample. Instead, dumny variables for nonreporting of each of these variables were included in the analyses and variables that were not reported were assıgned the value of zero. See G. S. Maddala (1977) for a discuission of estimation when observations on some variables are missing. 
11. We say "hls" throughout because over 97 percent of the approximately 1.010 superintendents who appear in our sample anyt lme aurıng the ilve-year perlod were males. Squared values ot $S_{3} \cdot S_{4}$, and $S_{5}$ (wh1ch a pure "human capltalist" might asert belong in the analyses) never proved significant, primarily we suspect because of the small age range over which $\mathrm{S}_{5}$ varied (most superintendents are over 40 ) and the large number of observations for which $S_{3}$ and $S_{4}$ were not reported.

12. We stress these are the superintendents' perceptions; school board members might respond differently.

13. We are grateful to Dr. Gordon Bruno, Superintendent of the Ithaca, NY City School District, for suggesting we include this request in our survey.

14. We isolate the third grade mathematics test because it was the only one of the four tests that did not undergo revision during the perlod and that was given in all flve years. As a result, whlle the entire battery of tests can be used to construct a periormance measure when analyzing a single year's cross-section. subsequent sections' iongitudinal analyses, which pool data across years, are restricted to using the single third grade mathematics test.

15. These unfortunately, were the only test score data that the New York State Education Department could provide us. It obviousiy would have been preferable to have test scores for older students and aiso to focus some attention on the upper tail of the achievement distribution. For example, data on high 
school graduation rates, or on the fraction of seniors going on to higher education would have been desirable. Our focus on the lower tail of the elementary school student test distribution imparts additional error to our educational performance measures, as does our ignoring other aspects of educational performance that are not easily measured (e.g., teaching students to write, or instilling a sense of social responsibility in them).

16. This restriction to "stayers" leads to obvious selectivity problems (see James Heckman (1979)) as it ignores the return to performance that comes from increased opportunity for mobility. This issue is addressed in the next section.

17. Data from the first academic year in the sample, 197879. is used only to construct the lagged performance measures for $1979-80$.

18. If some of the included variables are proxies for the - omitted ones and if these included ones are correlated with our performance measures, other (measurement error) problems may arise and the bias cannot always be signed. On this, see Zvi Griliches (1977).

19. A similar criticism applies, of course, to the earlier work of Goldstein and Ehrenberg (1976).

20. See Jerry Hausman (1978) for a discussion of the flxedeffects model.

21. Strlctly speaking, at first glance first-differencing may appear to eliminate the fixed effect only for stayers. Letting $j$, be the district superintendent $l$ is in in period 
$t-1$ (and prior) ana $k$ be the district he is in in period $t$, the generalization of ( 7 ) for movers would be

$$
\begin{aligned}
\log \left(W_{i k t} W_{i j t-1}\right) & =\alpha_{0 t}+\alpha_{1}\left(X_{k t}-X_{j t-1}\right)+\alpha_{2}\left(S_{i t}-S_{i t-1}\right) \\
& +\alpha_{3}\left(T_{i j t-1}-T_{i j t-2}\right)+\alpha_{4}\left(E_{i j t-1}-E_{i j t-2}\right) \\
& +\left(V_{k}-V_{j}\right)+\left(\varepsilon_{1 t}-\varepsilon_{1 t-1}\right)
\end{aligned}
$$

However, since presumably $P\left(V_{j}, T_{i j t-1}\right)=P\left(V_{j}, T_{i j t-2}\right)$ and $P\left(V_{j} \cdot E_{i j t-1}\right)=P\left(V_{j}, E_{i j t-2}\right)$, first-differencing should eliminate omitted varaible bias for movers as well.

22. The other district and superintendent characteristics (in $x$ and $S$ ) rarely changed, save for movers. and they are excluded here to avoid severe collinearity problems.

23. As above, Inclusion of the superintendent's salary in the base year did not alter any of the other coefficients. For the subset of school districts for which we had teacher salary data, we also attempted to test if school superintendents' salary changes were related to the salary changes of teachers in their school districts. This variable, however, never proved statistically significant.

24. These results are fully consistent with the crosssection salary equations found in Table 3.

25. See Madalla (1983).

26. See. especially. footnote 15 :

27. For discussions of methods to try to distinguish heterogenelty bias from other factors ( $1 . e .$. state dependence). 
see Chamberlain ( 1981 ) and Heckman (1981). Since this issue is not of central importance to us, we do not pur le these methods here.

28. As Table 10 indicates, when the change in tax performance specification is generalized and the base year and lagged year level entered separately, only the latter matters.

29. An additional concern is that the productivity-salary change-mobilitty relationships that we observe may reflect learning over time about superintendents' true productivity, and then attempts to compensate them for this true productivity rather than any incentive driven relationships. Kevin Murphy (forthcoming) has proposed tests (in the context of corporate executives compensation' to distin'uish between the "incentive" and "learning" explanations. His tests require good data on prior experlence and job tenure cboth are often missing in our samp (e).

30. This is computed as the stayer coefficient for the lagged math performance variable (.007) multiplied by the standard deviation of the math performance variable (.46).

31. This is computed as the implied mover coefficient for the lagged tax rate performance variable (.075) multiplied by the standard deviation of the tax rate performance variable (.23).

32. These are calculated as $\exp ((1.466)(.23))$ minus one and $\exp ((-2.006)(.23))$ minus one. respectively. 
Table 1

School Superintendents' Salaries in New York State: 1978-79 to $1982-83$

\begin{tabular}{lccccc} 
Year & $\begin{array}{l}\text { Number of } \\
\text { Districts } \\
\text { Reporting }\end{array}$ & Mean & $\begin{array}{l}\text { Std. } \\
\text { Dev. }\end{array}$ & Minimum & Maximum \\
\hline $1978-79$ & 701 & 34,964 & 8,325 & 17,500 & 58,500 \\
$1979-80$ & 700 & 36,614 & 8,617 & 17,500 & 61,500 \\
$1980-81$ & 698 & 38,936 & 8,978 & 18,500 & 64,500 \\
$1981-82$ & 689 & 41,665 & 9,479 & 22,785 & 71,000 \\
$1982-83$ & 675 & 44,227 & 9,887 & 20,000 & 71,000 \\
\hline
\end{tabular}

Source: Authors' calculations from data on the New York State Education Department's "Basic Educational Data System" (BEDS) School District Tapes for 1978-79 to 1982-83. Excluded each year are New York City, districts where the position is vacant, and districts that failed to report salary information. 
Table 2

Mobility of School Superintendents

in New York State: 1978-79 to 1982-83

Years

(A)

(B)

(C)

(D)

$1978-79$ to $1979-80$

727

$610(84 \%)$

$28(4 \%)$

$89(12 \%)$

$1979-80$ to $1980-81$

719

$624(87 \%)$

$29(4 \%)$

66

$1980-81$ to $1981-82$

715

$582(81 \%)$

$42(6 \%)$

$91(13 \%)$

$1981-82$ to $1982-83$

720

$634(88 \%)$

$28(4 \%)$

58

$(8 \%)$

where

(A) - number of superintendents in the sample in the first year

(B) - number (percent) of superintendents in the first year who were in the same district in the second year

(C) - number (percent) of superintendents in the first year who moved to another district in the state in the second year

(D) - number (percent) of superintendents in the first year who were not employed in any district in the sample in the second year

Source: Authors' calculations from data on the New York State Education Department's "Basic Educational Data System" (BEDS) School

District Tapes. 
Table 3

Determinants of School Superintendents' Salaries in New York State: Annual Cross-Sections

(absolute value of $t$ statistics)

\begin{tabular}{|c|c|c|c|c|c|}
\hline $\begin{array}{l}\text { Exp. }{ }^{a} / \text { Acad. } \\
\text { Var./Year }\end{array}$ & \multicolumn{5}{|c|}{ Logarithm of Annual Salary (SAL) } \\
\hline$x_{1}$ & $.127(22.5)$ & $.113(20.0)$ & $.117(21.2)$ & $.111(20.7)$ & $.110(20.0)$ \\
\hline$x_{2}$ & $.045(5.8)$ & $.025(4.1)$ & $.028(4.8)$ & $.019(3.9)$ & $.011(2.3)$ \\
\hline$x_{3}$ & $.191(5.2)$ & $.228(6.5)$ & $.228(6.3)$ & $.273(8.4)$ & $.294(9.3)$ \\
\hline$x_{4}$ & $.151 \quad(3.6)$ & $.146(3.4)$ & $.189(4.3)$ & $.152(3.6)$ & $.120(2.9)$ \\
\hline$x_{5}$ & $.178(2.6)$ & $.072(1.2)$ & $.032(0.4)$ & $-.071(1.0)$ & $-.111(1.7)$ \\
\hline$x_{6}$ & $.357(2.5)$ & $.449(3.0)$ & $.367(2.5)$ & $.445(3.1)$ & $.494(3.4)$ \\
\hline$x_{7}$ & $.200(2.0)$ & $.009(0.0)$ & $.027(0.3)$ & $-.001(0.0)$ & $.074(0.8)$ \\
\hline$x_{8}$ & $-.073(1.0)$ & $.022(0.3)$ & $-.049(0.7)$ & $-.036(0.5)$ & $-.080(1.0)$ \\
\hline$x_{9}$ & $.185(1.8)$ & $-.147(1.3)$ & $.105(1.1)$ & $.224(2.2)$ & $.218(2.1)$ \\
\hline $\mathrm{x}_{10}$ & $.014(1.0)$ & $.025(1.6)$ & $.000(0.0)$ & $-.019(1.2)$ & $-.012(0.9)$ \\
\hline $\mathrm{s}_{1}$ & $-.008(0.7)$ & $.006(0.6)$ & $.010(1.0)$ & $.013(1.4)$ & $.023(2.3)$ \\
\hline $\mathrm{S}_{2}$ & $.000(0.0)$ & $-.016(1.4)$ & $-.014(1.3)$ & $-.032(3.1)$ & $-.016(1.7)$ \\
\hline $\mathrm{S}_{3}$ & $.002(1.1)$ & $-.000(0.3)$ & $.001(0.6)$ & $-.000(0.1)$ & $-.000(0.2)$ \\
\hline $\mathrm{S}_{4}$ & $.006(5.3)$ & $.006(5.0)$ & $.006(5.5)$ & $.004(3.6)$ & $.007(5.7)$ \\
\hline$s_{5}$ & $.002(2.1)$ & $.003(3.3)$ & $: .002(2.1)$ & $\begin{array}{c}.002(2.2) \\
\cdot\end{array}$ & $.001(0.8)$ \\
\hline$\overline{\mathbf{R}}^{2}$ & .842 & .845 & .840 & .836 & .828 \\
\hline $\mathbf{n}$ & 590 & 557 & 558 & 570 & 574 \\
\hline
\end{tabular}

${ }^{a}$ Also included were an intercept term and dummy variables for nonreporting of the superintendents' previous experience, current job tenure, and year of bachelor's degree. Experience and job tenure were available for 35 to $65 \%$ of the sample each year, while year since degree was typically available for 70 to $80 \%$ of the sample. 


\section{Table 3 (continued)}

where

$\mathrm{x}_{1}=$ logarithm of total enrollment in the district in the year

$\mathrm{x}_{2}=$ logarithm of the full value of property in the district per enrolled student in the year

$x_{3}=$ logarithm of per capita personal income in the county in the year

$\mathrm{X}_{4}=$ logarithm of median family income in the district in 1979

$\mathrm{X}_{5}=1979$ percentage of the district's population that was nonwhite

$\mathrm{X}_{6}=1979$ percentage of the district's adult population with greater than a college education

$\mathrm{x}_{7}=1979$ percentage of the district's households with children at home

$\mathrm{X}_{8}=1979$ percentage owner-occupied housing in the district

- $\mathrm{X}_{9}=1979$ percentage of the district's adult population with some college or a college degree

$\mathrm{X}_{10}=1979$ percentage of the district's population residing in urban areas

$S_{1}=1$ =superintendent had a doctoral degree in the year, $0=$ no such degree in year

$S_{2}=1=$ superintendent had a certificate of advanced study in the year, $0=$ no such degree

$S_{3}=$ superintendent's total number of years experience in other school districts as a superintendent

$S_{4}=$ superintendent's years of tenure in the current district

$S_{5}=$ superintendent's years since receiving a bachelor's degree

\section{Sources:}

Authors' computations from:

1) Sal, $\mathrm{X}_{1}, \mathrm{X}_{2}$ - New York State Education Department, "Basic Educational Data System (BEDS) School District Tapes for 1978-79 to 1982-83, and New York State Education Department, "Financial Data System" (ST3) School District Tapes for 1978-79 to 1982-83.

2) $\mathrm{X}_{3}$ - U.S. Department of Commerce, Bureau of Economic Analysis, unpublished tabulations for 1978 to 1982.

3) $\mathrm{X}_{4}$ to $\mathrm{X}_{10}$ - U.S. Bureau of the Census, 1980 Census of Population, School District Data File for New York State.

4) $S_{1}$ to $S_{4}$ - American Association of School Administrators, Who's Who in Educational Administration, 1976-77, 1980-81 editions and the survey of school superintendents in New York State conducted by the authors in the summer of 1985 . 
Table 4

School Superintendents' Characteristics and the Size and Wealth of the District in Which They Are Employed

(absolute value of $t$ statistics)

\begin{tabular}{lcccccc} 
Acad. & \multicolumn{7}{c}{ Logarithm of Per Student } & Full Value \\
Var./Year & $1978-79$ & $1979-80$ & $1980-81$ & $1981-82$ & $1982-83$ \\
\hline $\mathrm{S}_{1}$ & $.113(1.7)$ & $.115(1.4)$ & $.144(1.8)$ & $.147(1.6)$ & $.205(2.3)$ \\
$\mathrm{S}_{2}$ & $.016(0.2)$ & $.153(1.5)$ & $.096(1.0)$ & $.208(2.0)$ & $.118(1.2)$ \\
$\mathrm{S}_{3}$ & $-.006(0.6)$ & $-.001(0.0)$ & $.003(0.3)$ & $.007(0.6)$ & $.006(0.6)$ \\
$\mathrm{S}_{5}$ & $.010(1.8)$ & $.011(1.7)$ & $.005(0.9)$ & $.010(1.3)$ & $.004(0.6)$ \\
\hline $\bar{R}^{2}$ & .016 & .006 & 563 & .010 & .024 & .025 \\
$\mathbf{n}$ & 596 & & 565 & 576 & 579 \\
\hline
\end{tabular}

Logarithm of Total Enrollment

\begin{tabular}{|c|c|c|c|c|c|}
\hline & $1978-79$ & $1979-80$ & $1980-81$ & $1981-82$ & $1982-83$ \\
\hline $\mathrm{s}_{1}$ & $.738 \quad(8.0)$ & $.733(7.9)$ & $.741(8.0)$ & $.702(7.8)$ & $.720(8.1)$ \\
\hline $\mathbf{S}_{2}$ & $.033(0.3)$ & $.005(0.0)$ & $.019(0.2)$ & $.115(1.1)$ & $.072(0.8)$ \\
\hline $\mathrm{s}_{3}$ & $.021(1.6)$ & $.017(1.3)$ & $.008(0.7)$ & $.016(1.5)$ & $.016(1.6)$ \\
\hline$s_{5}$ & $.033(4.4)$ & $.035(4.6)$ & $.033(4.5)$ & $.035(5.0)$ & $.034(4.8)$ \\
\hline$\overline{\mathbf{R}}^{2}$ & .180 & .190 & .177 & .190 & .199 \\
\hline $\mathbf{n}$ & 596 & 563 & 565 & 576 & 579 \\
\hline
\end{tabular}

also included in the analyses are an intercept term and dumny variables for nonreporting of year of bachelor's degree and years of experience as a superintendent prior to current job. All variables are defined as in Table 3. 
Table 5

New York State Public School Superintendents' Perceptions

of the Criteria School Boards Use in

Evaluating Their Performance

1) Overall Response to the Survey

2) Response to Question on Criteria Used in Evaluation

3) Mentioned that Criteria Included:

a) Community/Pubic Relations

b) School Board Relations

c) Staff and Personnel Management

d) Fiscal Management

e) Curriculum Development, Educational Planning and Leadership

f) Professional and Personal Development

g) General Management and Administration

h) Academic Performance and Achievement

1) Facilities Management

j) Student Services and Relations

k) Student Discipline

1) Parent Relations

${ }^{a}$ Responses from the approximately 700 school superintendents in New York State (excluding New York City) to a survey conducted by the authors in May to July of 1985 . Response rates did not vary substantially across size classes of school districts. 
Table 6

1979-80 Tax Rate and Educational Outcome Equations

(absolute value of $t$ statistics)

Explanatory/

Variables / Outcome

$\log (T)$

$\log (G M)$

$\log (\mathrm{AS})$

$\mathrm{x}_{2}$

$-.100(7.0)$

$-.036(1.2)$

$-.033(1.6)$

$\mathrm{x}_{3}$

$-.001(0.0)$

$-.243(1.3)$

$-.029(0.2)$

$\mathrm{x}_{4}$

$.180(1.8)$

$-.253(1.2)$

$-.397(2.8)$

$x_{5}$

$.691(4.6)$

$1.351(4.2)$

$1.111(5.2)$

$x_{6}$

$1.009(2.8)$

-1.331 (1.8)

$-1.801(3.5)$

$\mathrm{x}_{7}$

$.979(3.7)$

$.670(1.2)$

$.374(1.0)$

$\mathrm{x}_{8}$

$-.417(2.1)$

$-.689(1.7)$

$-.653(2.3)$

$\mathrm{x}_{9}$

$.388(1.4)$

$-.685(1.2)$

$-.634(1.7)$

$\mathrm{x}_{10}$

$.271(7.6)$

$-.042(0.6)$

$-.009(0.2)$

D

$.006(0.1)$

:278 (2.9)

.205 (3.1)

$\overline{\mathbf{R}}^{2}$

n
.457

573
.184

565
.349

568

where

$T=$ fuil value property tax rate in the school district in 1979-80

GM = percentage of the district's students who scored below the state reference point on standardized 6 th grade mathematics exam in 1979-80

AS = average of the percentages of the district's students who fell below the state reference point on standardized 3 rd and 6 th grade reading and mathematics exams in 1979-80

$D=1=c i t y$ school district (school board sets tax rate), $0=0$ ther school district (voters approve school budget in annual referendum)

Sources: Authors' calculations from:

1) $x_{2}$ to $x_{10}$ - defined as before, see Table 3 .

2) T - New York State Education Department, "Financial Data System" (ST3) School District Tape for 19.79-80.

3) GM, AS - New York State Education Department, Pupil Evaluation Program (PEP) Test Scores. 
Table 7

Effects of Performance Measures on School Superinitendents'

Salaries: Annual Cross-Sections of "Stayers"

(absolute value of $t$ statistics)

Pooled

$1979-80$ to

$1979-80$

$1980-81$

$1981-82$

1982-83

Mode1 1

$\mathrm{TP}$

$-.026(1.5)$

$-.029(1.5)$

$-.008(0.4)$

$.004(0.3)$

$-.022(2.3)$

MP

$.016(1.7)$

$-.013(1.5)$

$.004(0.5)$

$.016(2.0)$

$.005(1.1)$

$\bullet$

Mode1 2

TP

$$
-.026(1.5)
$$

$-.028(1.5)$

$-.007(0.4)$

$.005(0.3)$

$-.022(2.3)$

AP

$.016(1.7)$

$-.003(0.2)$

$.020(1.7)$

$.012(1.4)$

$.013(2.3)$

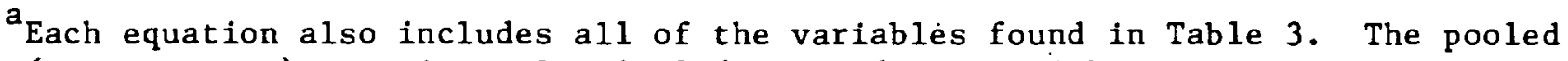
(across years) equations also include year dummy variables.

TP - tax performance measure $=10 g$ (predicted tax rate) minus log (actual tax rate) in the previous academic year.

MP - math performance measure $=10 g$ (predicted percentage of students who fell below state reference point on 6 th grade.math test) minus $\log$ (actual percentage) in the previous academic year.

AP - average educational performance measure $=10 g$ (predicted average percentage of students who fell below state reference point on 3rd and 6 th grade reading and math tests) minus $\log$ (actual percentage) in the previous academic year.

Positive values for each performance measure indicate above average performance. 
Table 8

Salary Change Equations for Superintendents who Stay in the Same Position or Move to Another Position

in New York State ${ }^{a}$.

(absolute value $t$ statistics)

(1)

(2)

(3)

(4)

\begin{tabular}{|c|c|c|c|c|}
\hline c & $.061(37.9)$ & $.077(8.5)$ & $.074(9.6)$ & $.079(8.7)$ \\
\hline Y81 & $.020(7.3)$ & $.010(2.9)$ & $.018(6.3)$ & $.010(3.0)$ \\
\hline Y82 & $.006(2.3)$ & $-.003(0.5)$ & $.003(0.7)$ & $-.004(0.8)$ \\
\hline M & $.060(10.0)$ & $-.063(5.0)$ & $-.050(4.7)$ & $-.055(4.4)$ \\
\hline$\% \Delta \mathrm{Y}$ & & $-.098(1.2)$ & $-.120(1.7)$ & $-.110(1.4)$ \\
\hline$\% \Delta E$ & & $-.010(0.2)$ & $.010(0.3)$ & $-.004(0.1)$ \\
\hline$\% \triangle A$ & & $.004(0.6)$ & $.004 \quad(0.7)$ & $.003(0.5)$ \\
\hline$\triangle M P$ & & $-.005(1.7)$ & & \\
\hline$\Delta \mathrm{TP}$ & & $.007 \quad(0.6)$ & & \\
\hline MPB & & . & $.002(0.8)$ & \\
\hline TPB & & & $.005(1.0)$ & \\
\hline MPL & & & & $.007(2.5)$ \\
\hline TPL & & & & $.008(1.3)$ \\
\hline$M * \% \Delta Y$ & & $.446(5.3)$ & $.411(5.5)$ & $.425(5.0)$ \\
\hline$M * \% \Delta E$ & & $.120(3.0)$ & $.093(2.9)$ & $.105(2.6)$ \\
\hline$M * \% \Delta \mathrm{A}$ & & $.052(4.1)$ & $.013(1.5)$ & $.052(4.1)$ \\
\hline$M \star \triangle M P$ & &. $.052(2.9)$ & & \\
\hline$M * \Delta \mathrm{TP}$ & & $-.331 \quad(4.5)$ & & \\
\hline$M * \mathrm{MP}_{\mathrm{B}}$ & & & $.009(0.6)$ & \\
\hline${ }^{M * T P}{ }_{B}$ & & & $-.013(0.5)$ & \\
\hline $\mathrm{M}^{\star \mathrm{MP}}{ }_{\mathrm{L}}$ & & & & $-.038(2.8)$ \\
\hline$M * \mathrm{TP}_{\mathrm{L}}$ & & & & $.067(2.2)$ \\
\hline $\mathrm{n}$ & 2208 & 1200 & 1901 & 1210 \\
\hline$\overline{\mathrm{R}}^{2}$ & .066 & .331 & .260 & .322 \\
\hline
\end{tabular}

${ }^{a}$ Including the log of the base period salary as an additional explanatory varlable only marginally affected the other coefficlents. 
Table 8 (continued)

where

Y81 1 if 1980-81 to 1981-82 change observation, 0 otherwise

Y82 1 if 1981-82 to 1982-83 change observation, 0 otherwise

M 1=move to another superintendency in New York State; $0=0$ ther

$7 \Delta Y \quad$ change in the logarithm of per capita personal income in the county the superintendent's school district is located in from the base (first) to new (second) year

7LE change in the logarithm of total enrollment in the superintendent's school district from the base to new year

\% $\triangle \mathrm{A} \quad$ change in the logarithm of the full value of property per enrolled student in the superintendent's school district from the base to the new year

$\triangle \mathrm{MP}, \Delta \mathrm{TP}$ change in the math test (tax rate) performance measure from the lagged (year prior to the base) to the base year

$\mathbf{M P}_{\mathbf{B}}, \mathbf{T P}_{\mathbf{B}}$ math test (tax rate) performance measure in the base year

${ }^{M P} P_{L}, T P_{L}$ math test (tax rate) performance measure in the lagged year

and

Correlation Matrix of

Performance Measures

$\begin{array}{llll}\mathrm{MP}_{\mathrm{B}} & .522 & .082 & .060 \\ \mathrm{MP}_{\mathrm{L}} & & .061 & .066 \\ \mathrm{TP}_{\mathrm{B}} & & & .891 \\ & \mathrm{MP}_{\mathrm{L}} & \mathrm{TP}_{\mathrm{B}} & \mathrm{TP}_{\mathrm{L}}\end{array}$

Implied Effects of Performance

Variables on the Salary Changes of Movers

(2)

(3)

$\triangle M P .047(2.6) \quad \mathrm{MP}_{\mathrm{B}} .011(0.8) \quad \mathrm{MP}_{\mathrm{L}}-.032(2.4)$

$\Delta \mathrm{TP}-.324(4.5) \quad \mathrm{TP}_{\mathrm{B}}-.008 \quad(0.3) \quad \mathrm{TP}_{\mathrm{L}} \quad .075(2.5)$ 
Table 9

Multinomial Logit Analyses ${ }^{a}$

(absolute value $t$ statistics)

4-Way Dichotomy

$\frac{P \text { (move, } \dot{S}>0)}{P(\text { stay })} \quad \frac{P \text { (move, } \dot{S} \leq 0)}{P(\text { stay })} \quad \frac{P(\text { leave sample) }}{P(\text { stay })}$

3-Way Dichotomy

$\frac{P(\text { move }, \dot{S}>0)}{P(\text { stay })} \quad \frac{P(\text { move }, \dot{S} \leq 0)}{P(\text { stay })}$

\begin{tabular}{lrrrrrrrr}
\hline $\mathrm{C}$ & $45.263(4.2)$ & $13.167(1.0)$ & $-5.494(1.3)$ & $43.996(4.1)$ & $13.193(1.0)$ \\
$\mathrm{Y} 81$ & $.645(1.8)$ & $.071(0.1)$ & $.530(2.3)$ & $.656(1.8)$ & $.114(0.2)$ \\
$\mathrm{Y} 82$ & $-1.670(2.8)$ & $.149(0.2)$ & $.054(0.2)$ & $-1.671(2.7)$ & $.180(0.3)$ \\
$\mathrm{MP}_{\mathrm{L}}$ &.$- .128(0.4)$ & $-.448(0.8)$ & $-.255(1.1)$ & $-.147(0.4)$ & $-.487(0.9)$ \\
$\mathrm{TP}_{\mathrm{L}}$ & $1.466(2.0)$ & $-2.006(1.7)$ & $-.176(0.4)$ & $1.460(2.0)$ & $-2.136(1.7)$ \\
$\mathrm{CDEG}$ & $.050(0.1)$ & $-.029(0.0)$ & $-.194(0.4)$ & $.063(0.1)$ & $-.035(0.0)$ \\
$\mathrm{DDEG}$ & $1.307(3.0)$ & $.586(0.9)$ & $.368(1.3)$ & $1.292(2.9)$ & $.579(0.9)$ \\
$\mathrm{AGE}$ & $-.062(1.9)$ & $-.049(0.8)$ & $.089(3.8)$ & $-.055(1.7)$ & $-.045(0.8)$ \\
$\mathrm{TEN}$ & $-.014(0.2)$ & $.075(1.1)$ & $-.004(0.1)$ & $-.020(0.3)$ & $.071(1.0)$ \\
EXP & $.121(3.0)$ & $.144(2.2)$ & $-.086(0.7)$ & $.120(3.0)$ & $.144(2.2)$ \\
LENR & $-.009(0.3)$ & $.039(0.1)$ & $.037(0.3)$ & $-.056(0.2)$ & $.039(0.1)$ \\
LFULI & $-.202(0.7)$ & $.164(0.8)$ & $-.164(1.1)$ & $-.256(0.9)$ & $.156(0.8)$ \\
LMFI & $-4.637(3.9)$ & $-1.927(1.4)$ & $-.254(0.5)$ & $-4.462(3.7)$ & $-1.946(1.4)$
\end{tabular}

${ }^{a}$ Also included in the analyses were dummy variables for nonreporting of age, tenure at base year job, and experience as a superintendent on previous jobs.

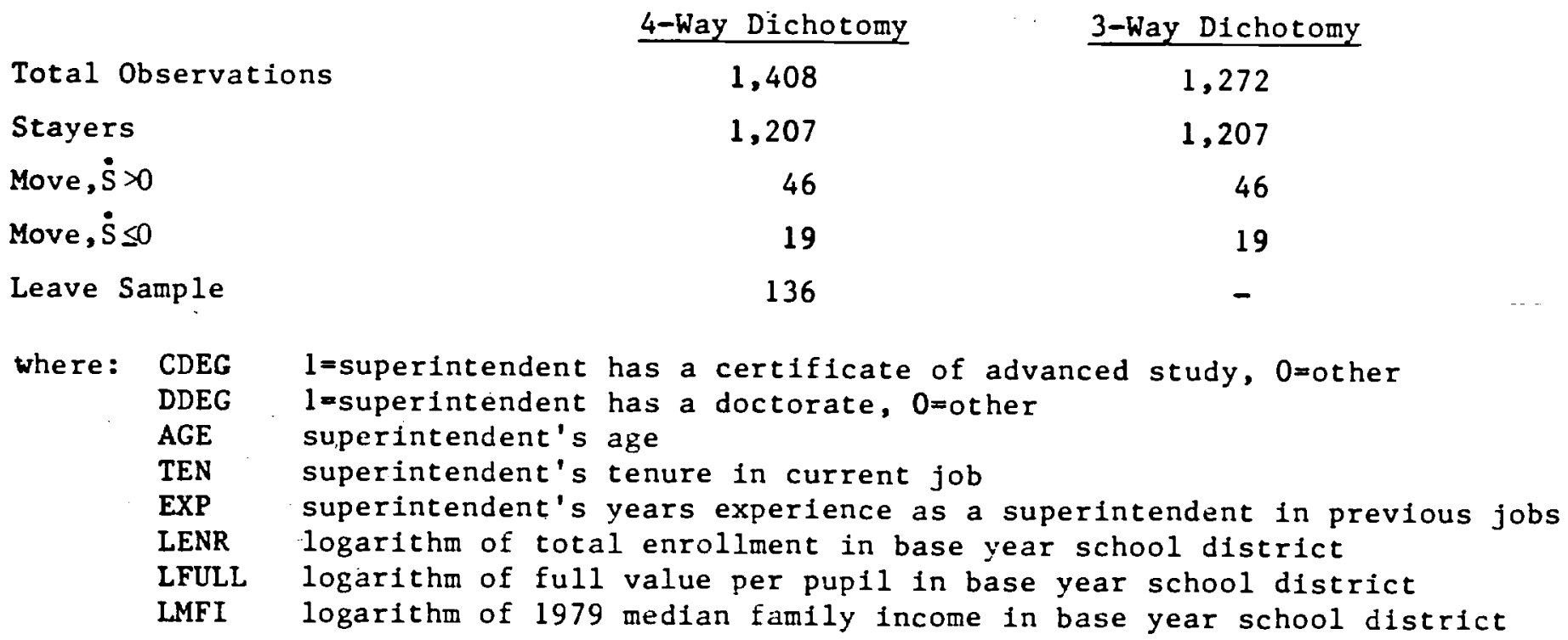


Table 10

Summary of Performance Variable Coefficients, Various Multinomial Logit Specifications: 4-Way Dichotomy (absolute value $t$ statistics)

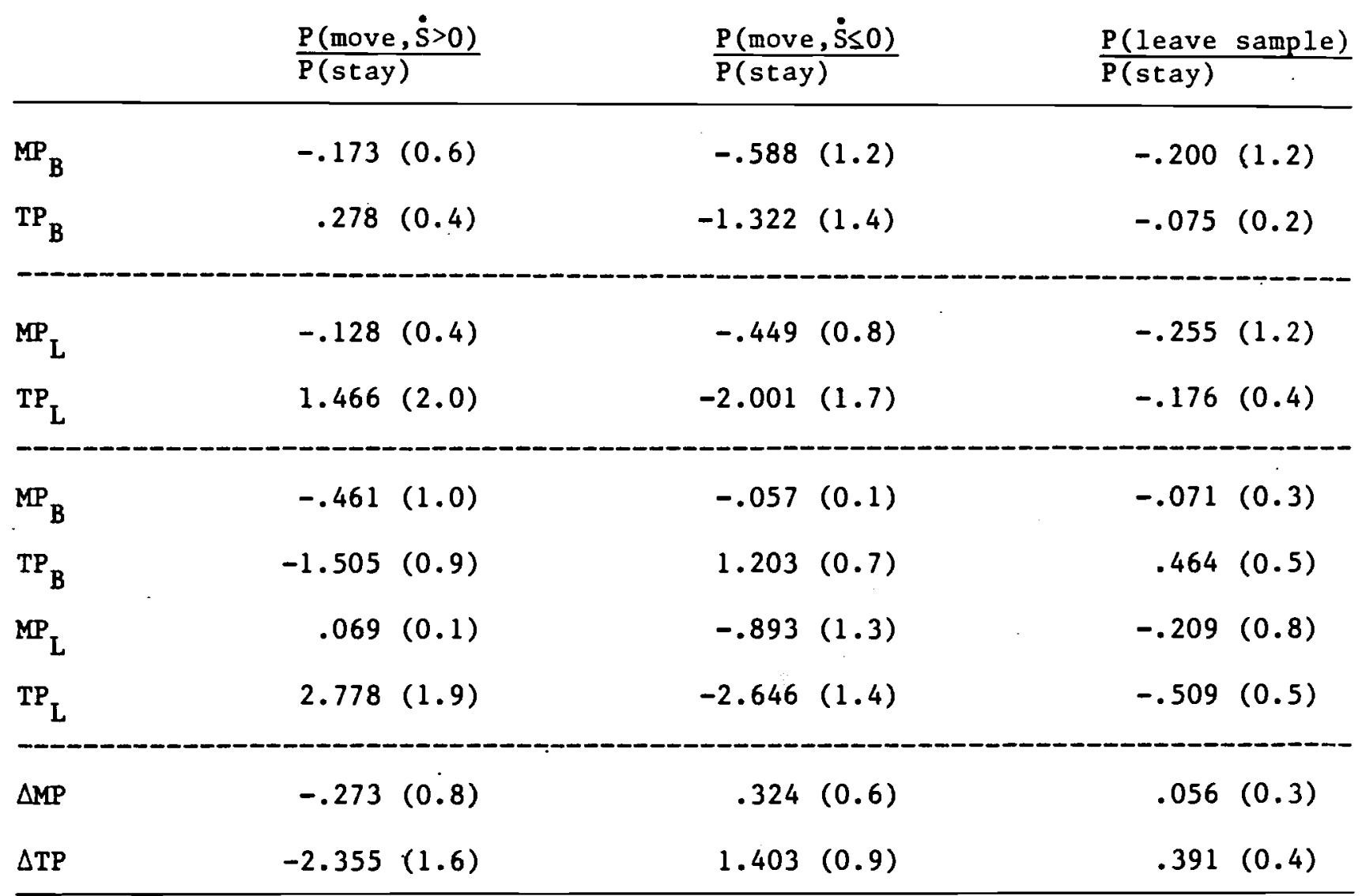

${ }^{a}$ Also included in each model were all of the explanatory variables found in the models in Table 9. When either the logarithm of the base year salary, the residual from a salary equation that included only characteristics of the superintendent, the residual from a salary equation that included characteristics of the superintendent and the school district in which he was employed, or the residual from salary equations that also included performance measures, were included in the models, the pattern of signs and significance of the coefficients in this table were not altered. Moreover, neither the wage level, nor any of the residuals, ever proved to be statistically significant. 